\title{
TRANS STUDIO ANIMASI
}

\author{
Erica Hosanna ${ }^{1)}$, Mieke Choandi ${ }^{2)}$ \\ ${ }^{1)}$ Program Studi S1 Arsitektur, Fakultas Teknik, Universitas Tarumanagara, erica.hosanna@gmail.com \\ ${ }^{2)}$ Program Studi S1 Arsitektur, Fakultas Teknik, Universitas Tarumanagara, miekec@ft.untar.ac.id
}

\begin{abstract}
Abstrak
Animasi merupakan sebuah prospek yang sedang meningkat dalam Indonesia, tetapi perkembangan ini tidak dapat apresiasi dengan baik. Disini munculah kesempatan untuk menggunakan animasi sebagai atraksi wisata lokal.Trans Studio Animasi merupakan sebuah indoor theme park dengan tema animasi. Dengan lokasinya yang terletak pada CBD Puri Kembangan, diharapkan bahwa Trans Studio Animasi dapat membuat kawasan menjadi kawasan Tourism Bussiness District yang lebih baik.
\end{abstract}

Kata kunci: animasi, indoor theme park, tourism business district, trans studio

\begin{abstract}
Animation just recently became a rising prospect in Indonesia, however there was not enough platform to showcase local works. There rises a possibility to use animation as part of the local tourism attraction. Trans Studio, a famous indoor theme park line with the theme of "being inside the television", have a good opportunity to make this happen. Trans Animation Studio will provide otherworldly experience to tourists. Located in Puri CBD, this project hopes to strengthen the tourism business district by attracting local to worldwide tourists.
\end{abstract}

Keyword: animations, indoor theme park, tourism business district, trans studio

\section{PENDAHULUAN}

\section{Latar Belakang}

Animasi pada Indonesia merupakan sebuah prospek bisnis yang sedang meningkat semenjak 2010an, dan ditandai dengan Battle of Surabaya oleh MSV Studio pada 2015 yang booming di cinema tentang semangat patriotik. Badan Ekonomi Kreatif (2015) mencatat naiknya PDB ekonomi kreatif pada subsector Animasi Video sebanyak 6,68\%, dan pada subsector Desain Komunikasi Visual sebanyak 10,28\%. Kedua subsektor tersebut merupakan 2 dari 4 subsektor yang tercatat telah berkembang sangat pesat semenjak 2010. Hal ini menandakan bahwa Animasi merupakan suatu bidang yang banyak diminati dan ingin dikembangkan oleh warga, memiliki komunitas yang erat, dan memiliki potensi dan inovasi untuk berkembang lebih jauh, dengan jumlah peminat yang bertambah seiring waktu. Apa yang bisa dilakukan untuk memadai perkembangan ini? Pariwisata di Indonesia memiliki perkembangan semenjak 1980an. Warga lokal tidak sungkan untuk menempuh perjalan yang jauh demi melihat dan merasakan suasana baru. Aktifitas ini yang dulunya merupakan aktifitas yang mahal dengan berkembangnya kawasan urban, jalan dan akses transportasi, sekarang menjadi hal yang umum. Wisata konvensional sudah merupakan aktifitas lazim dengan menggunakan teknologi, masyarakat mulai memanfaatkan teknologi dalam progress wisata.

Wisata animasi, dengan menggunakan teknologi terbaru merupakan seesuatu yang belum muncul di Indonesia. Teknologi dapat mempresentasikan animasi dalam berbagai hal dan media baru, dan teknologi dapat membuka berbagai pintu untuk atraksi menarik. Trans Animation Studio pada Kembangan Selatan menggunakan lokasi Carrefour yang sekarang sudah jarang dikunjungi. Jumlah pengunjung Carefour Kembangan Selatan terjadi penurunan hingga tinggal 20\% dari jumlah rata-rata Carrefour lainnya dan dengan kepemilikan Carrefour yang sekarang adalah milik Transmart (TransTV), Lokasi Carrefour Kembangan Selatan berada di pusat aktifitas Jakarta Barat merupakan lokasi yang ideal. 


\section{METODE}

Metode Pembahasan dalam proses penulisan Tugas Akhir ini menggunakan metode bertahap. Pertama, tahap pengumpulan data dilakukan dengan metode survey, wawancara, dan observasi. Data lalu melalui metode induksi komparatif. Hasil induksi akan melalui metode deduksi untuk merumuskan konsep.

\section{DISKUSI DAN HASIL METODE}

\section{Kajian Teori}

Trans Studio

Trans Studio adalah tempat hiburan indoor yang dikembangkan oleh Trans Media (PT Trans Corporation). Trans Studio berupa tempat wisata indoor, dengan tema-tema seperti program acara televisi yang terdapat pada TransTV dan Trans7. (TransMedia).

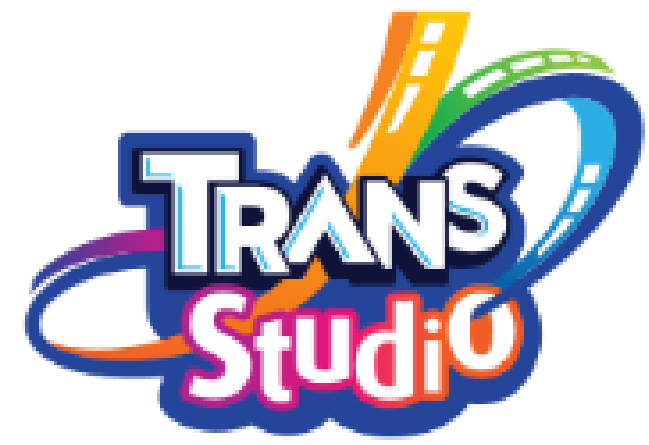

Gambar 1. Logo Transtudio

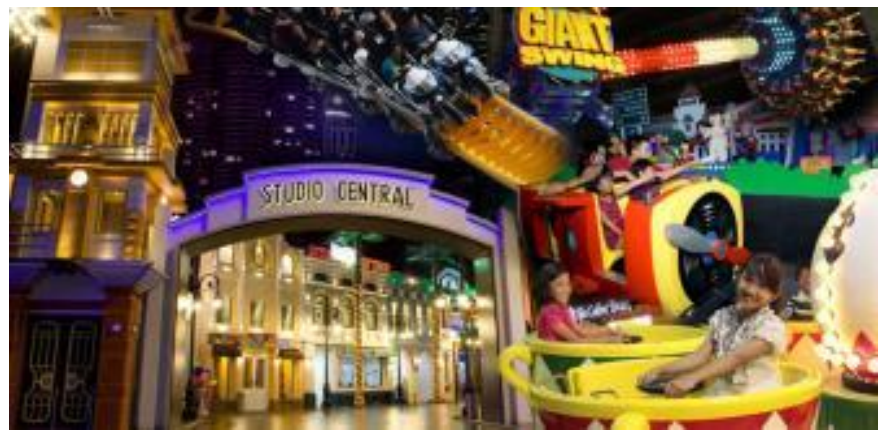

Gambar 2. Trans Studio

\section{Tempat Hiburan}

Aspek terpenting dari sebuah tempat hiburan adalah untuk membuat pengunjungnya tersenyum (Edwin Nafarin, 2018). Beberapa aspek yang perlu diperhitungkan pada sebuah tempat hiburan adalah;

a. Story, sebuah cerita yang menentukan alur tempat hiburan tersebut,

b. Perception, persepsi dari masing-masing pengunjung, dimana setiap pengunjung memiliki pendapat yang berbeda dan unik ketika melihat sesuatu.

c. Memories, dimana hal-hal pada tempat hiburan mengingatkan pengunjung padaingatan masa lalu.

d. Dan Surprise, dimana pengunjung dikejutkan dengan sesuatu yang baru, unik atau memukau pada setiap tingkungan.

Tempat hiburan memunculkan perasaan terkaitnya diri pengunjung kepada suatu setting yang terpisah dari rutin keseharian (DC Raluka, 2008). Salah satu metode tempat hiburan untuk memberi kesan "terisolasi dari rutin keseharian" adalah melalui rekayasa atmosfer dari sebuah waktu dan tempat lain. Hal ini umumnya ditunjukkan melalui arsitektur, atraksi, tokotoko, karakter, dan pertunjukkan yang ada di lokasi tersebut. Contoh terkenal adalah Disneyland, yang menggunakan cerita salah satu princess-nya sebagai tema, sehingga terdapat 
sebuah istana, toko-toko, atraksi, dan karakter yang berhubungan dengan princess tersebut. Beberapa tema umum yang sering digunakan adalah zaman sejarah, legenda, binatang, laut, dan futurism. Masing-masing tema merupakan sebuah tempat terisolasi.

\section{Teknologi Hiburan}

Teknologi terbaru merupakan salah satu demand tertinggi pada sarana hiburan. Alat terbaru, teknologi digital dan efek khusus dirancang untuk memberikan sebuah faktor muhtahir dengan menggunakan cahaya, kostum, efek visual. Teknologi seperti ini memeiliki potensi untuk digunakan sebagai bagian dari Trans Animation Studio.

Rides

Salah satu teknologi hiburan, seperti pada tempat hiburan Dufan dan Transtudio, merupakan teknologi rides yang bersifat linear. Mereka bergerak pada alur yang sudah ditentukan. Sirkulasi yang digunakan untuk sebuah ride dapat memakan banyak tempat, sehingga tempat hiburan secara umumnya menggunakan ruang yang luas, tetapi tidak dengan teknologi hiburan terbaru. Rides terbaru menggunakan kombinasi proyeksi dan $4 d$ effects seperti hembusan angin, air, dan 360 motion untuk memberi sebuah ilusi bahwa ride hiburan bergerak, walaupun ride hanya berdiam pada lokasinya. Teknologi ini tidak memakan banyak tempat, dan sifatnya yang digital membuatnya fleksible, dimana proyeksi, animasi dan efek bisa berubah sesuai kebutuhan.

\section{Sensory Immersion}

Adalah dimana sensor pengunjung diransang untuk merasakan sesuatu hal tertentu. Teknologi ini memiliki potensi tinggi pada sebuah tempat hiburan. Sebagai tempat yang merekayasa dunia lain, dan tempat yang perlu menghadirkkan suatu yang baru terus menerus untuk mendatangankan pengunjung, teknologi sensory immersion dapat merevolusi industry hiburan (Creativiva,2017). Dengan teknologi ini, maka tempat hiburan dapat menekan biaya pembuatan instalasi fisik, mengurangi kebutuhan ruang untuk sebuah gudang, dan masih dapat merubah tema seasonal dengan mudah. Hal ini memungkinkan karena teknologi berdasarkan digital dan proyeksi

Pada saat ini, potensi terbesar untuk pengembangan profesional adalah pengalaman yang mendalam: augmented reality, Virtual Reality, dan video $360^{\circ}$ interaktif. Sementara instalasi Sensory Immersion yang terkenal di Indonesia berupa Infinity World dan Museum MACAN (Yayoi Kusama) dimana ruang fisik dipasang cermin dan cahaya untuk memberi kesan ruang yang tiada akhirnya.

\section{Interactive Technology}

Dengan ini hal-hal bersifat teknologi dan mesin dapat berinteraksi dengan pengunjung, memberi sebuah dimensi tambahan kepada pengunjung (Creativiva). Dengan aplikasi teknologi hiburan, maka tempat hiburan memiliki potensi untuk mengurangi penggunaan ruang yang digunakan oleh atraksi, dapat memiliki lebih banyak cara dalam menghibur dan berinteraksi dengan pengunjungnya, dan memiliki potensi untuk menjadi fleksible.

\section{Wisata di Metropolis}

Tidak jarang untuk menemukan tempat wisata yang berdekatan antar satu sama lain, terutama pada kota sepadat Jakarta. Seperti pada Grand Indonesia, yang terletak pada Jakarta Pusat. Grand Indonesia berdekatan dengan Plaza Indonesia, dan tidak jauh dari lokasinya, terdapat Thamrin City. Pola seperti ini dapat dilihat di beberapa titik Jakarta lainnya seperti CBD Puri, Emporium Pluit Mall, dan Senayan.

Inilah sebuah Tourism Business District, yang terdapat campuran antara fungsi komersial utama pada kawasan dengan fungsi pariwisata, (City Spaces Tourist Spaces) lebih umumnya 
digunakan oleh pengunjung daerah tersebut. Terdapat kawasan wisata lainnya berupa heritage precinct, waterfront, dan lainnya.

Masing-masing kawasan, dengan daya tariknya yang berbeda dengan satu sama lain, memiliki kesamaan, yaitu letak fungsi wisata yang berdekatan dengan fungsi wisata lain atau fungsi komersial lain. Kawasan seperti ini dapat menarik wisatawan yang tertarik untuk sebuah one-stop all. Inilah yang disebut Tourism Cluster, sebuah kawasan dengan berbagai titik wisata yang berdekatan.

\section{Dampak Wisata Hiburan Dalam Kota}

Merancang sebuah wisata pada kota biasanya didatangi dengan berbagai sisi positif dan negatif (Cartinel, 2008). Lingkungan tempat hiburan umumnya berdampak negative kepada linkungan fisik sekitar. Karena dirancang khusus untuk pengunjung modern, polusi visual seperti bangunan dan struktur yang tidak menarik merupakan hal yang umum, Polusi lainnya mencakup polusi cahaya, udara, suara, air, kemacetan kendaraan. Ada baiknya jika dalam merancang sebuah tempat hiburan untuk memperhitungkan daya dukung atau kejenuhan daerah.

Sebuah tempat hiburan dapat mengubah pola budaya pada kawasan. Karena tempat hiburan menyebabkan kenaikan interaksi antara orang lokal dan pengunjung, dan akan memiliki masalah jika terletak pada kawasan bersejarah. Bisa juga terjadi konflik seperti bahasa, budaya, perebutan fasilitas umum seperti transportasi. Tetapi disaat bersamaan, wisata dapat membuat kondisi hidup orang lokal menjadi lebih baik. Fasilitas umum akan dikembangkan dan keuntungan ekonomi dari pariwisata disebarkan Jika wisata teresebut dapat mencapai tingkat internasional, akan mendapat berbagai keuntungan (Jan Specht) seperti tersebarnya nama negaranya, bukti bahwa negara tersebut maju dan kaya.

\section{Instagramabilitas}

Pengunjung Millenial dan iGen mementingkan sosial media untuk jati diri mereka. Mereka berusaha untuk memasang foto-foto instagramable di akun sosial media mereka. Instagrambale adalah dimana sebuah foto atau video akan tampak baik di sosial media (Urban Dictionary), kata tersebut dimulai dari sosial media Instagram.

Survey dijalan untuk yang berusia 33 tahun dan lebih muda, 40\% dari mereka menyatakan bahwa instagamibilitas merupakan faktor penting dalam memilih lokasi wisata (Schofields,2016). Dan ini bukan karena kontes popularitas. Bagi mereka, Likes pada Instagram menandakan bahwa tempat tersebut banyak diminati dan indah dilihat.

Restoran, café dan Museum merupakan gerakan pertama yang menyesuaikan designnya untuk fenomena ini. Refinery 29 dan Museum of Ice Cream menyediakan tempat foto khusus seperti ruang yang dipenuhi dengan sprinkle. Di Indonesia sendiri sudah terdapat Museum Macan dan Infinity World yang menyediakan ruangan dengan permainan cahaya, ruang dan polka dot.

Fenomena Instagramisasi mulai menentukan bagaimana ruang arsitketur terbentuk. Arsitektur yang dirancang harus memenuhi keinginan Milenial dan iGen ini.

\section{Teori Perancangan Arsitektur}

Untuk merancang sebuah arsitektur yang unik, terdapat beberapa hal yang harus dipertimbangkan menurut Capon (1999) :

- Impartiality of form adalah pembentukan ruang sesuai objektif dan aturan - aturan ketertiban, kesederhanaan, kepresisian, dan prinsip tatanan.

- Efficiency of function adalah tujuan dasar berarsitektur bahwa suatu bangunan harus berfungsi efektif dalam segala aspek, mulai dari kenyamanan layout keseluruhan hingga hal yang paling mendetail dan mempengaruhi penggunaannya sehari-hari

- Integrity of meaning adalah prinsip pola pikir yang digunakan saat merancang. 
- Regard for context adalah bagaimana dapat bangunan memiliki harmonisasi dengan lingkungannya.

- Motivation of spirit penjiwaan dalam arsitektur untuk memunculkan perubahan dan variasi dalam berarsitektur.

Dalam perancangan, impartiality of form dan regard for context dapat dicapai melalui analisa tapak dan studi tipologi. Integrity of meaning dan motivation of spirit dapat terbentuk dari tujuan dan konsep perancangan.

\section{Program Aktifitas}

Dengan total KLB yang tinggi, maka Trans Studio Animasi akan dibangun berdampingan dengan sebuah hotel. Dengan ini akan terbentuk sebuah one stop all untuk fungsi wisata. Zoning fungsi untuk Trans Studio Animasi memiliki kisaran :

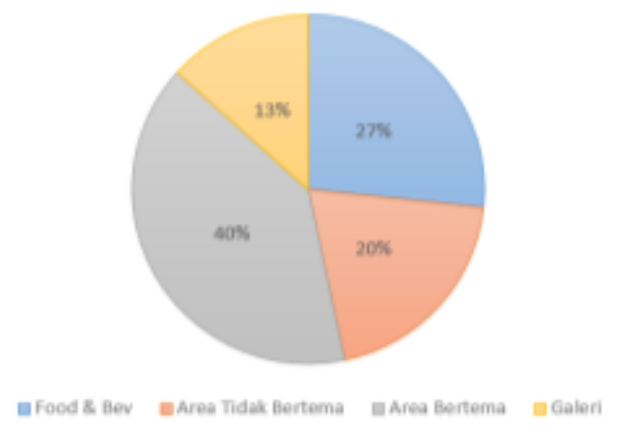

Diagram 1. Persentase Fungsi

a. Tenant

Merupakan salah satu daya tarik bangunan. Tenant berisi lebih banyak makanan dan minuman, tetapi bisa juga digunakan untuk tenant fashion dll.

b. Hiburan Utama

Hiburan tidak bertema berupa sebuah Museum Animasi, yang mengajari tentang sejarah animasi, dan sebuah Studio Animasi, dimana pengunjung bisa merasakan bagaimana bekerja dalam bidang animasi. Disini adalah zona dimana pengunjung belajar tentang animasi dan proses pembuatan animasi. Hiburan bertema pada theme park umumnya bersifak fisik. Seperti rumah hantu pada Dunia Fantasy, dimana pengunjung memasuki ruang remang dan gelap, dengan mesin "hantu" yang bergerak, serta suara ketawa menyeramkan yang dimainkan pada speaker. Hiburan bertema pada Trans Animation Studio tidak bersifat seperti ini, melainkan menggunakan proyeksi, dan bersifat digital. Beberapa tema umum digunakan, seperti Horror, Fantasy, Futuristik, Sejarah, dan Budaya Lokal. (Terdapat pilihan lain seperti Binatang, Galaxy dan lain-lain. Perlu dijalankan survey untuk mengetahui tema mana yang paling diminati)

c. Hotel

Hotel merupakan fungsi utama lainnya yang tidak termasuk dalam perancangan ini, tetapi akan disediakan akses dan sirktulasi vertical untuk ke hotel.

\section{Program Utama Hiburan Trans Studio Animasi}

a. Ruang Bertema

Trans Studio Animasi menyediakan ruang bertema yang dirancang mengikuti beberapa film animasi ternama. Ruang interior dihias dan diberi pencahayaan agar berupa dunia lain.

b. Acara / Pameran Seasonal

Trans Animation Studio bisa menyediakan atraksi seasonal, dan bisa mengikuti animasi 
atau perfilman yang sedang trending. Jika sekitar masa penayangan film horror Annabele (2016) maka pada ruang bertema horror akan menggunakan tema Annabele, dan ketika trend berpinidah dan It (2017) maka bagian horror dari Trans Animation Studio akan mengikuti, dan seterusnya. Hal ini memungkinkan karena atraksi bersifat digital dan hanya berupa proyeksi, tidak terdapat unsur fisik selain proyektor dan pemisah ruang yang digunakan. Hal ini juga memastikan bahwa Trans Animation Studio akan terus menghadirkan suatu yang baru untuk menarik pengunjung yang telah mendatangi Trans Animation Studio.

c. Fasilitas Outdoor

Trans Animation Studio merupakan wisata yang dibangun dengan tangan manusia, dan memerlukan biaya operasional yang tinggi, sehingga untuk berwisata ke Trans animation studio akan memungut biaya. Trans Animation Studio dikhususkan untuk keluarga menengah, keatas. Untuk keluarga menengah bawah, dan kebawah, maka akan disediakan aktifitas berupa taman bermain, yang tidak memungut biaya.

Fasilitas lain yang disediakan adalah fasilitas penunjang berupa :

- Restoran atau Café karena kebutuhan pengunjung untuk istirahat dan makan.

- Game Center yang menghadirkan game unik berupa Human Crane Game. Kids playground, dll

- Fasilitas Outdoor untukorang-orang yang kurang mampu

- Taman sebagi bagian dari ruang hijau dan tempat istirahat

Program Penunjang

- Ruang Entrance/Lobby penanda sudah berada di zona lain.

- Foto Spot untuk titik instagramable.

- Ruang Operator untuk mengoperasi atraksinya.

- Sebuah ruang staff kecil dan tempat penyimpanan barandan toilet

- Ruang Sekuritas, Ruang CCTV

- Ruang Staff

- Ruang operasional inti \& Ruang Teknik

- Ruang Genset, plumbing, pengudaraan

- Loading Dock \& Gudang

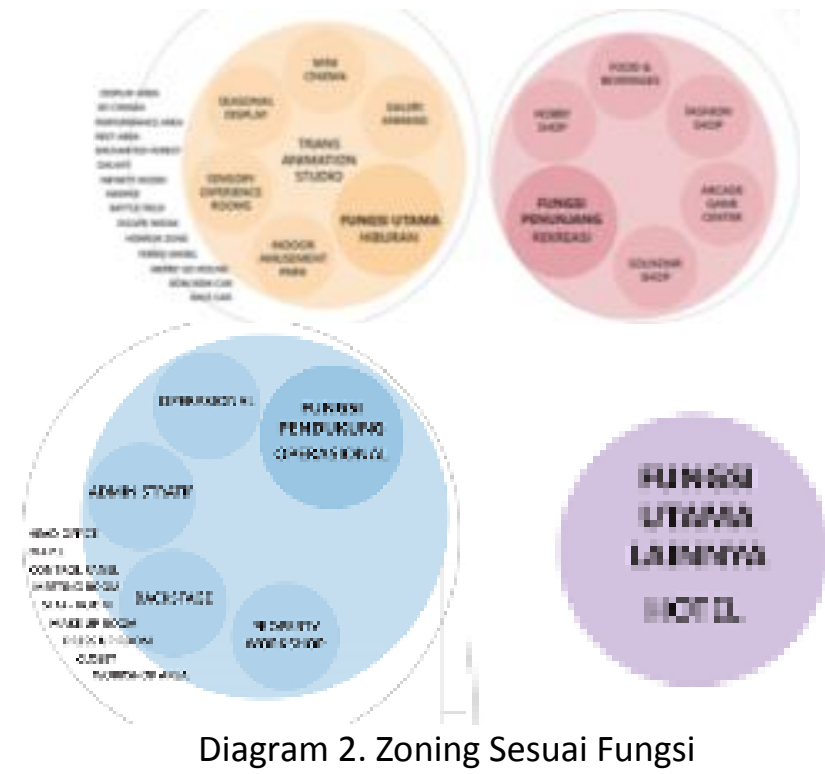




\section{Analisa}

Pemilihan Lokasi

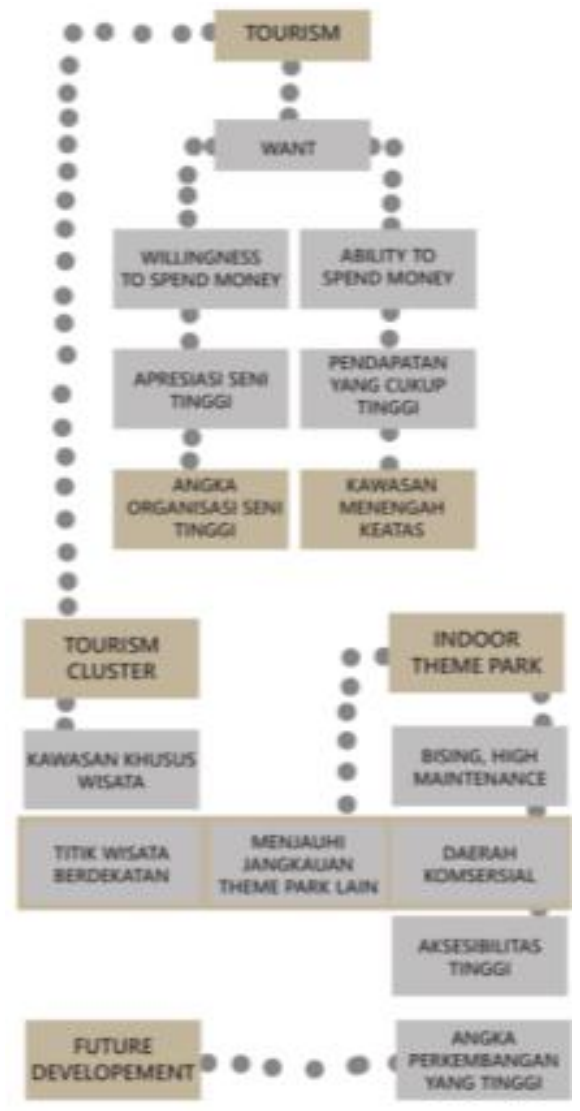

Diagram 3. Kriteria Pemilihan Lokasi

Karena kategori Trans Animation Studio adalah sebuah tempat hiburan, maka ketika memilih kawasan akan dipilih beberapa kirteria, seperti pada Diagram 3.1.
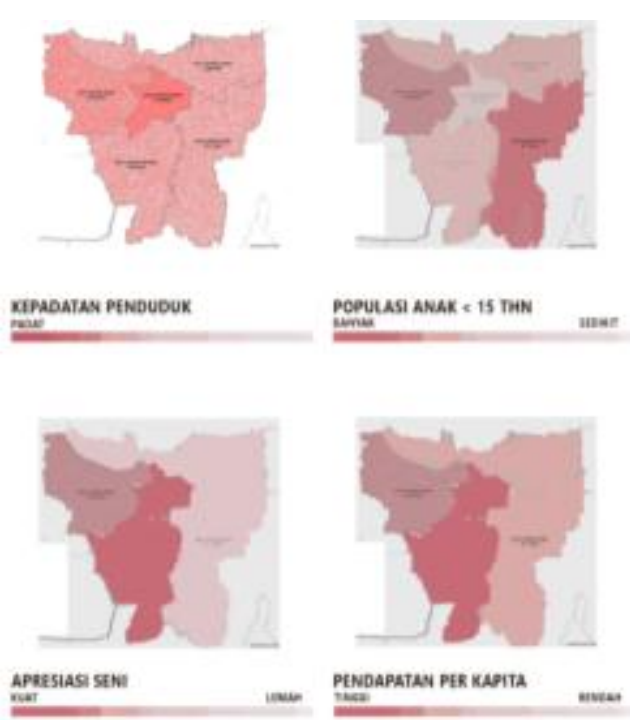

PENDAPATAY PER KaYTTA

Gambar 3. Mapping Jakarta Sesuai Diagram 1.

Jakarta Barat merupakan kawasan ke-2 terpadat pada Jakarta dan ke-2 terbanyak dalam populasi anak dibawah umur 15 tahun. Dengan apressiasi seni ke 2 tertinggi setelah Jakarta Pusat dan Selatan, dan pendatapan ke-2 tertingi setelah Jakarta Pusat dan Selatan Hal-hal ini 
menandakan bahwa Jakarta Barat adalah kawasan yang memiliki kriteria paling cocok untuk pengembangan Trans Studio Animasi.

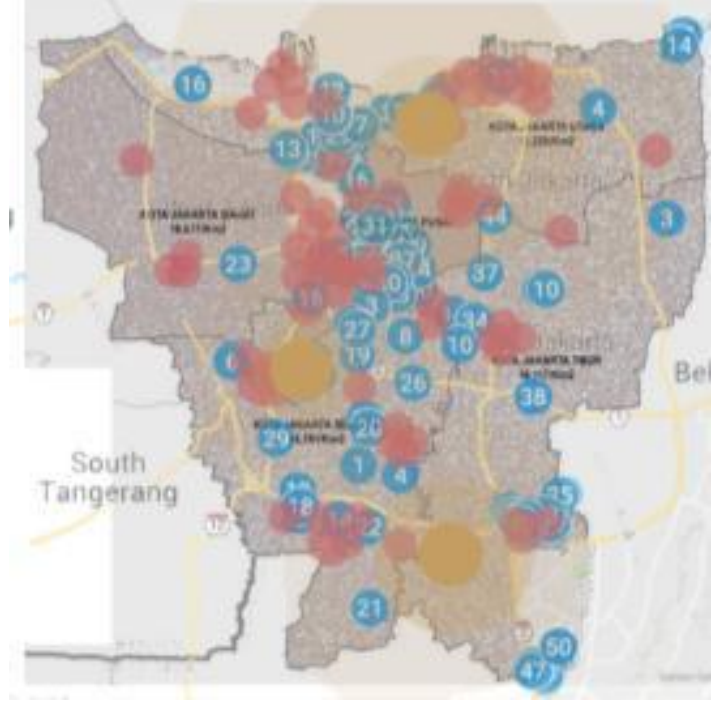

Gambar 4. Mapping Wisata Jakarta

Titik Wisata Jakarta

Titik Wisata Perbelanjaan

Titik Wisata Taman Hiburan

Tempat wisata berpusat pada Jakarta Pusat, Utara dan Selatan. Jakarta Barat memiliki jumlah titik wisata paling sedikit. Pusat wisata perbelanjaan terdapat pada Jakarta Pusat, diikuti dengan Jakarta Selatan dan Utara. Ancol memliki daya tarik paling tinggi sebagai salah satu kawasan wisata terbesar. Daya tarik tidak mencakupi seluruh Jakarta Barat. Terdapat 1 titik dimana wisata perbelanjaan di Jakarta Barat berpusat, yaitu kawasan CBD Puri Kembangan.

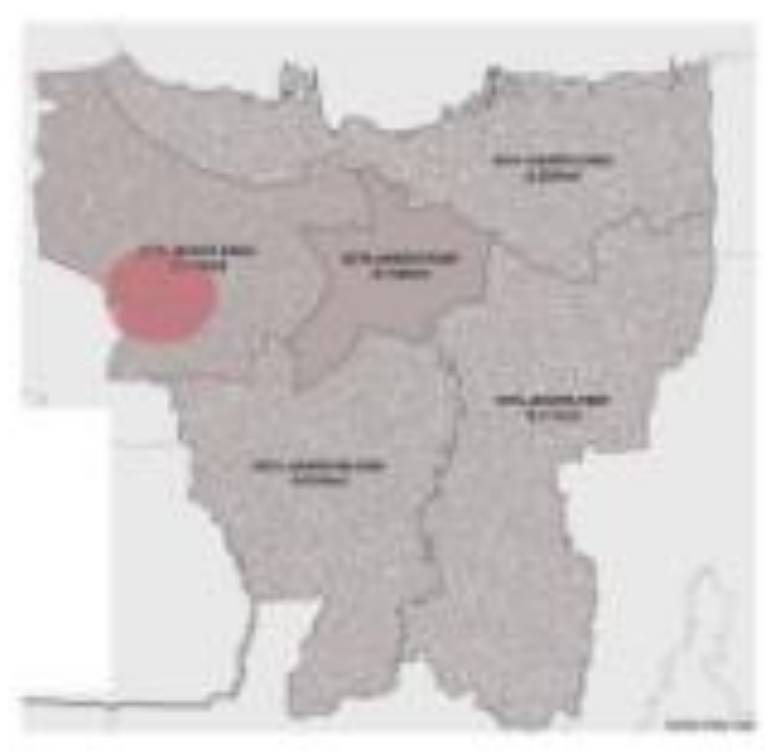

Gambar 5. Kawasan Terpilih 
Tabel 1. Peraturan Tapak

\begin{tabular}{|c|c|c|}
\hline & 04.002.K.2.a.b & Total \\
\hline Luas Tanah & $1.84 \mathrm{Ha}$ & $1.84 \mathrm{Ha}$ \\
\hline KDB & 50 & $0.97 \mathrm{Ha}$ \\
\hline KLB & 5 & $9.20 \mathrm{Ha}$ \\
\hline KDH & 25 & $0.46 \mathrm{Ha}$ \\
\hline KTB & 60 & $1.10 \mathrm{Ha}$ \\
\hline KB & 32 lantai & \\
\hline
\end{tabular}

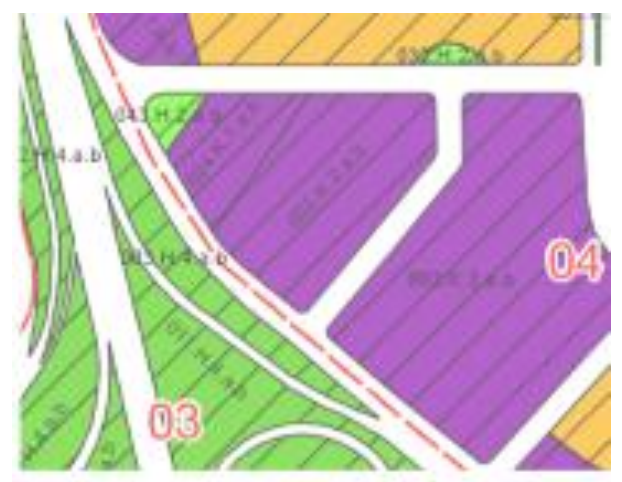

Gambar 6. Zonasi Tapak

\section{Analisa Lokasi Perancangan}

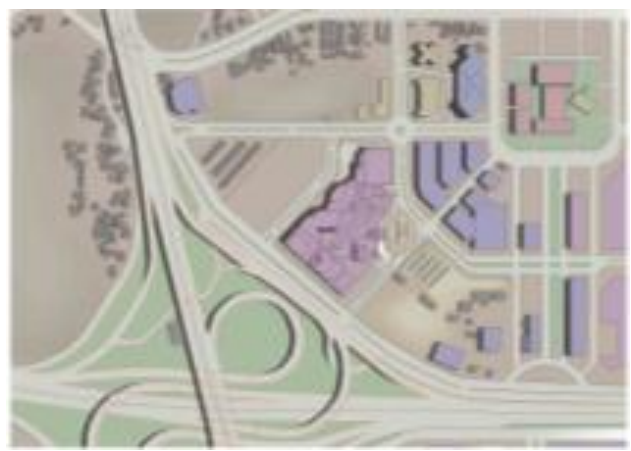

Gambar 7. Mapping Existing Terhadap Peraturan Tata Kota

Fungsi bangunan dipisah sesuai warna. CBD Puri memiliki fungsi bisnis dan rekreasi yang tinggi.

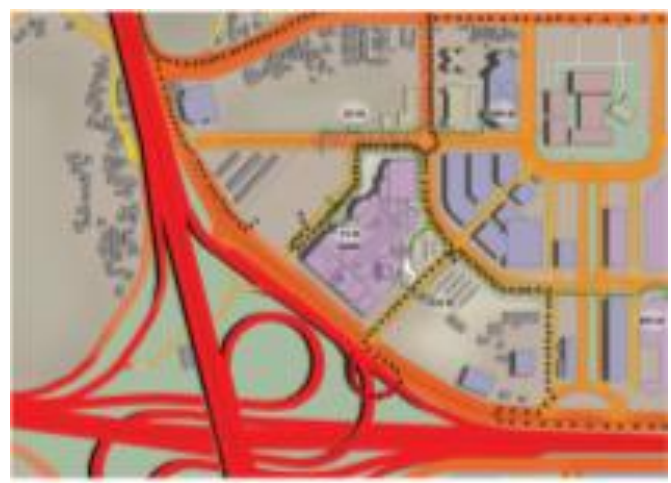

Gambar 8. Mapping Hirarki Jalan 
Jalan tol merupakan hirarki jalan tertinggi karena merupakan jalan tol negara. Ini diikuti oleh Jl. Puri Lingkar Luard dan JI. Puri Indah Raya yang mengelilingi CBD Puri.

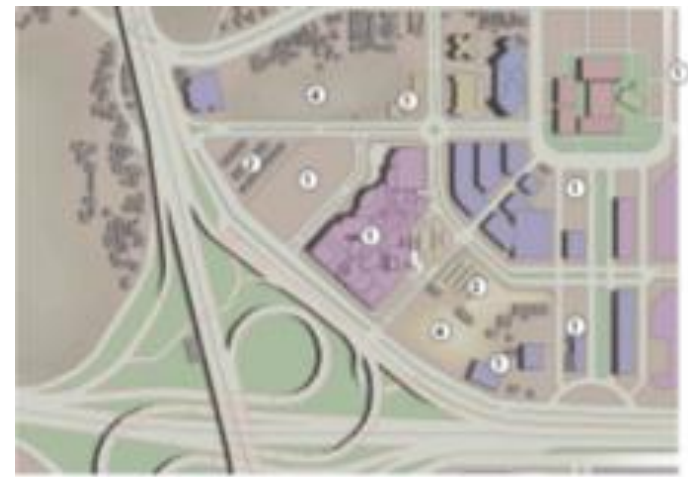

Gambar 9. Mapping Kesesuaian Bangunan dengan Peraturan

Banyak tapak pada CBD Puri belum memenuhi peraturan tanah. Peraturan yang tidak ditaati berupa:

1. KLB yang tidak terpenuhi.

2. Gudang yang tidak sesuai fungsi yang ditentukan

3. Tempat Parkir umum yang tidak sesuai fungsi yang ditentukan

4. Tanah masih kosong, belum mulai pembangunan

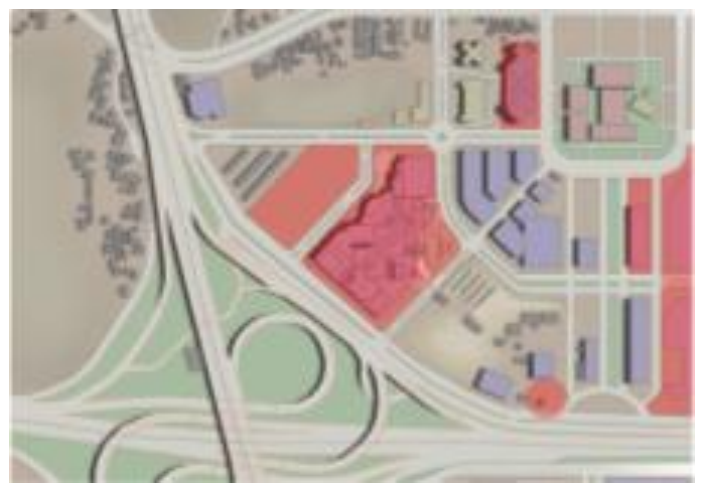

Gambar 10. Mapping Intensitas Aktifitas pada Hari Kerja

Intensitas tertinggi pada hari kerja terdapat pada Superblok Lippo Puri, dengan kantor highrise yang menjadi pusat untuk bekerja diikuti oleh Apartemen, Kantor Walikota, dan Ruko Puri.

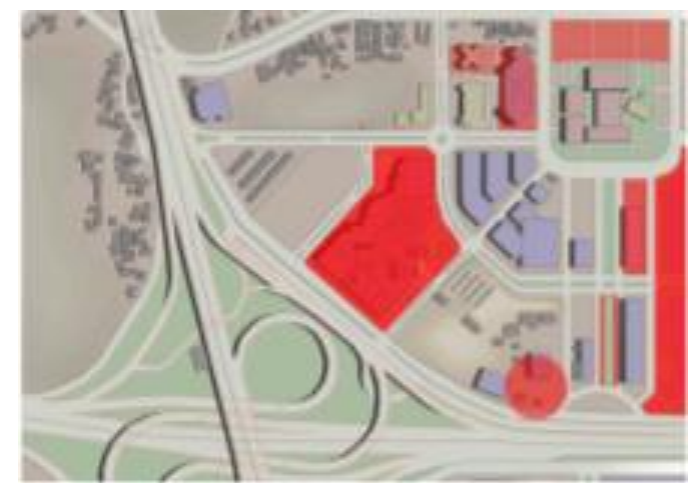

Gambar 11. Mapping Intensitas Aktifitas pada Hari Libur

Intensitas aktifitas tertinggi pada hari libur terpusat pada Superblok Lippo Puri dan Puri Indah Mall, sebagai pusat rekreasi, diikuti dengan Px Pavilion yang merupakan pusat kuliner. 


\section{Analisa Mikro}
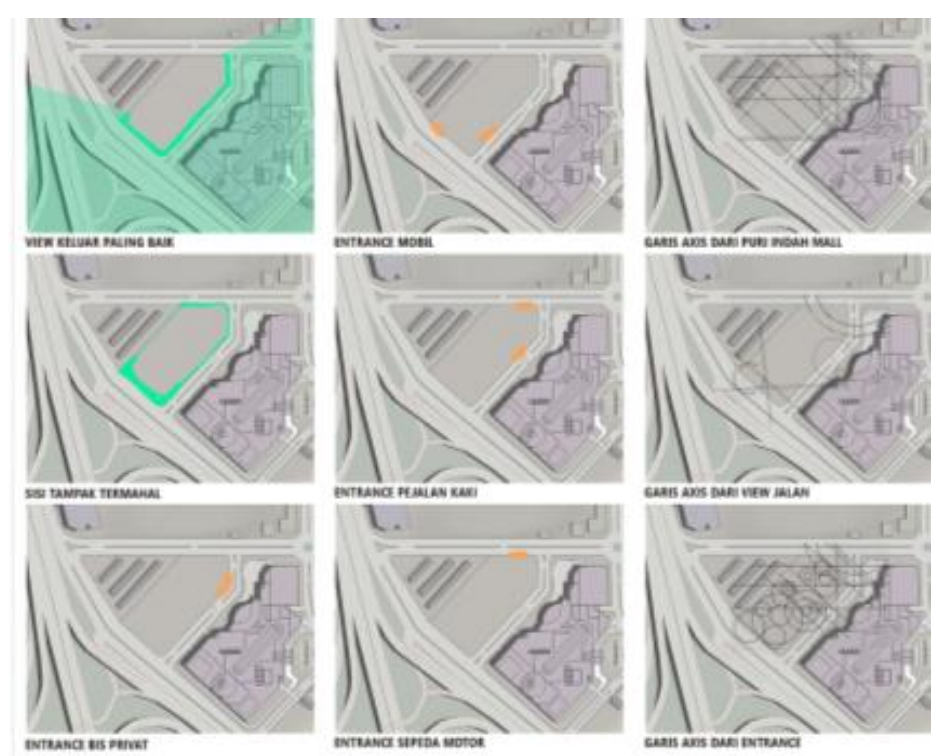

Gambar 12. Analisa Tapak Mikro

\section{Zoning}

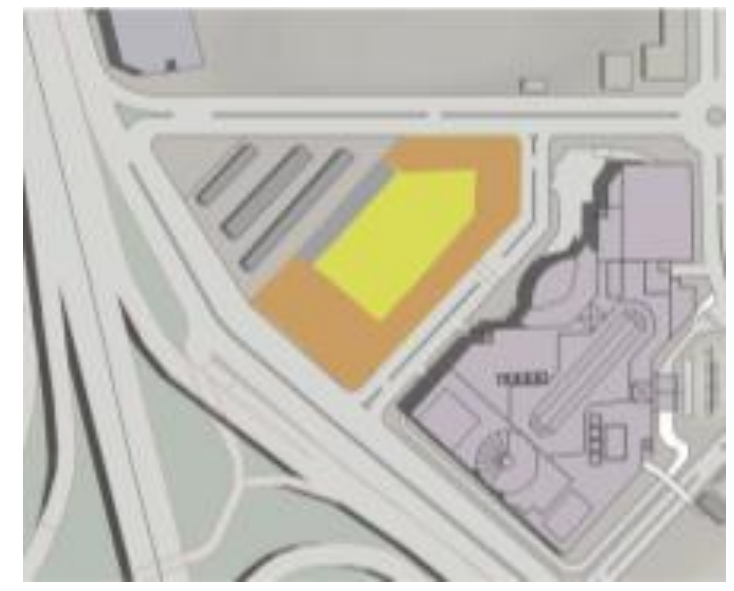

Gambar 13. Zoning Publik dan Privat

Pertama ditentukan zoning publik, semi publik, dan servis. Zoning publik terletak seiring jalan, sementara zoning semi public dikelilingi oleh zoning publik. Zoning servis terletak pada sisi yang tertutup dengan tapak pada samping.

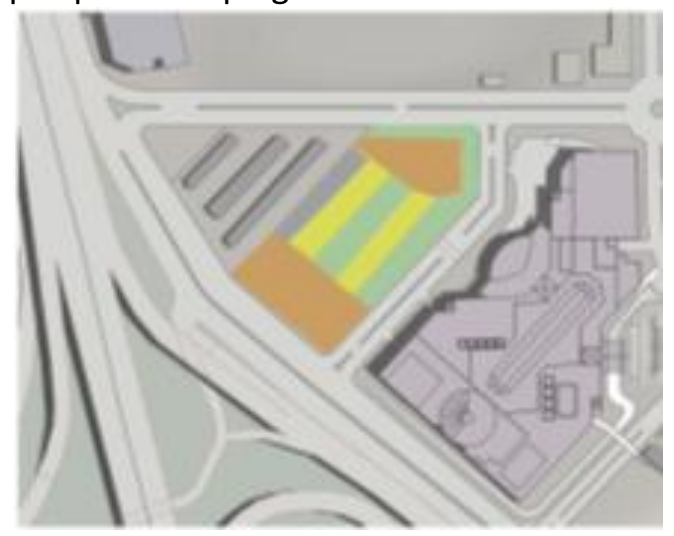

Gambar 14. Penempatan Area Hijau 
Area hijau dipisah menjadi 2 bagian; 1. Bagian yang mengiringi jalan, 2 bagian yang menjadi pusat aktifitas. Area hijau juga berfungsi sebagai transis dari lingkungan ke bangunan.

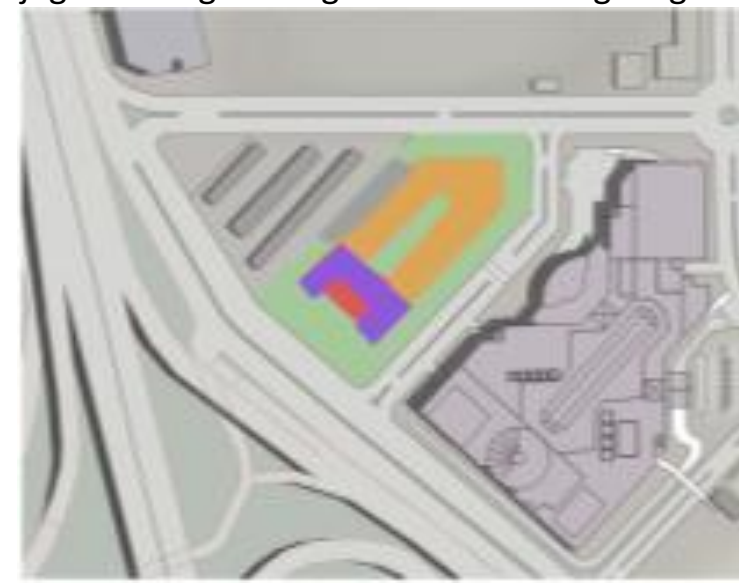

Gambar 15. Penempatan Area Hijau

Area hijau mengelilingi tapak, dan Zoning Hotel berada di sisi jalan dengan hirarki tertinggi. Zoning untuk Trans Studio Animasi terletak lebih dekat dengan Halte Bis.

\section{Penentuan Bentuk Gubahan Massa secara 2 Dimensi}

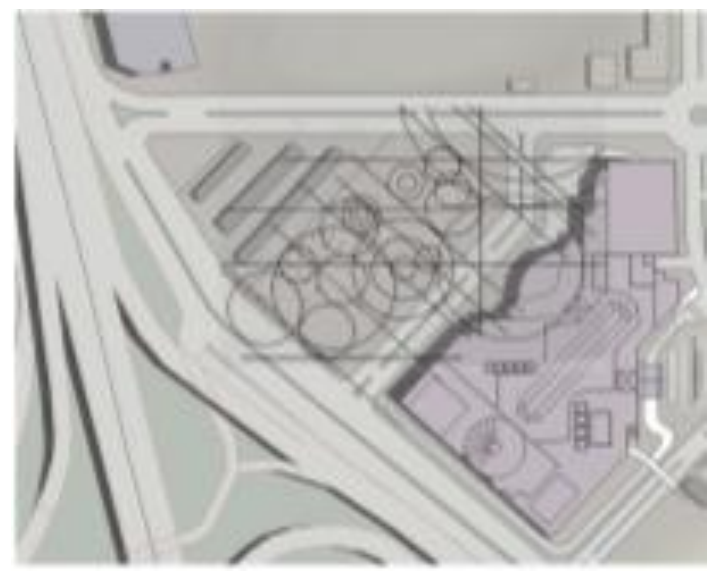

Gambar 16. Penarikan Garis

Garis patokan dari sekitar tapak ditarik. Garis bisa berupa pusat aktifitas, sudut view, dari halte bis, atau dari Puri Indah Mall.

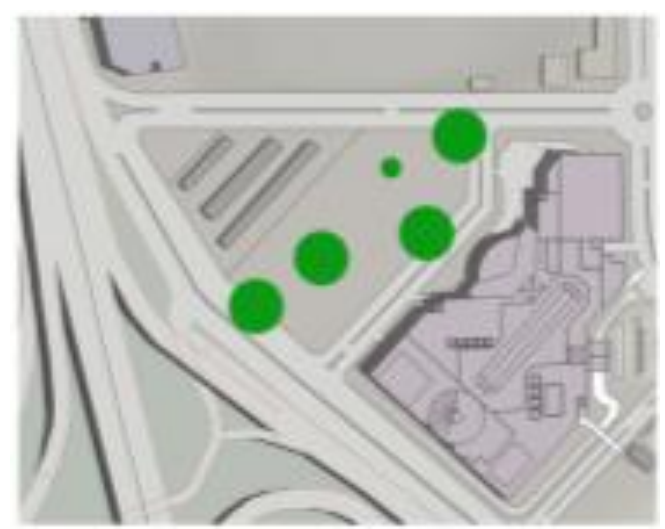

Gambar 17. Penarikan Garis 
Lingkaran pusat aktifitas ditentukan daari Gambar sebelumnya. Ini bisa berupa ruang luar, ruang hijau, dan entrance.

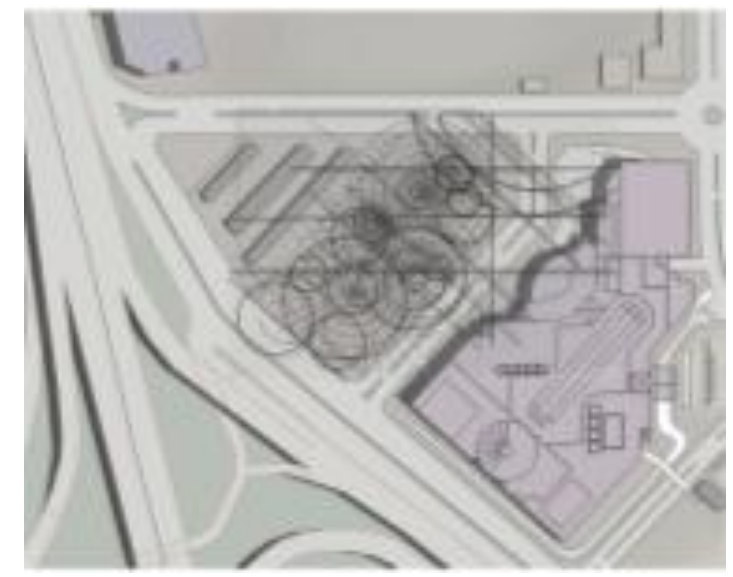

Gambar 18. Penentuan Modul

Menentukan modul pada garis-garis yang sudah ada. Modul berbentuk radial, dengan pusatnya yang diambil dari Gambar Penarikan Garis.

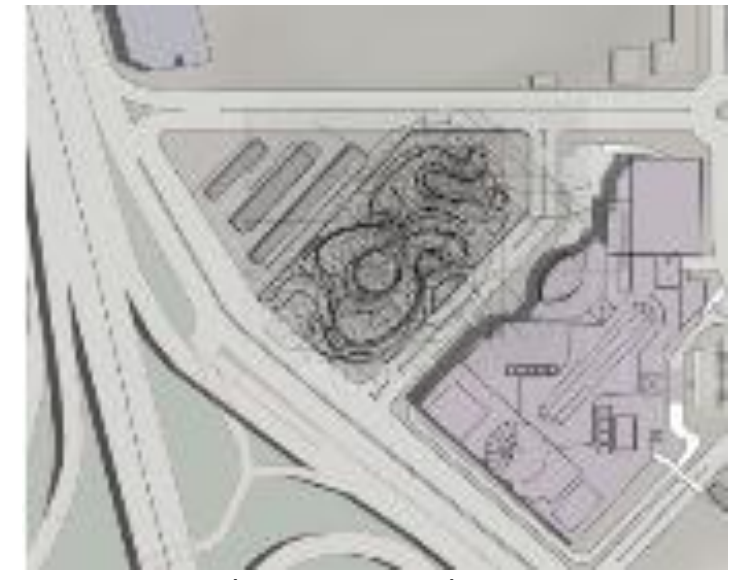

Gambar 19. Penarikan Garis

Bentuk bangunan mengikuti garis patokan yang sudah ada.

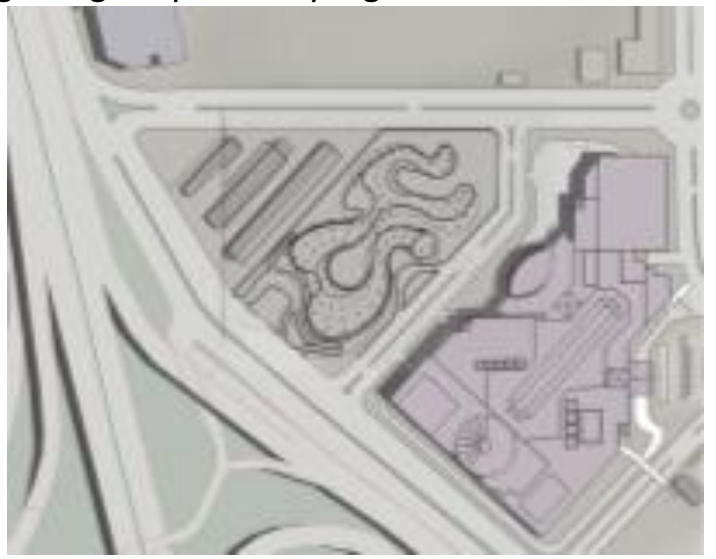

Gambar 20. Hasil Akhir Bentuk Bangunan Secara 2D

\section{Konsep}

Diagram menjelaskan tentanng pola piker saat merancang Trans Studio Animasi. Karena penekanan pada "Dunia Lain", "Seperti Dalam Animasi", dan "Terisolasi", maka tema yang dipilih adalah "Negri di Awan," 

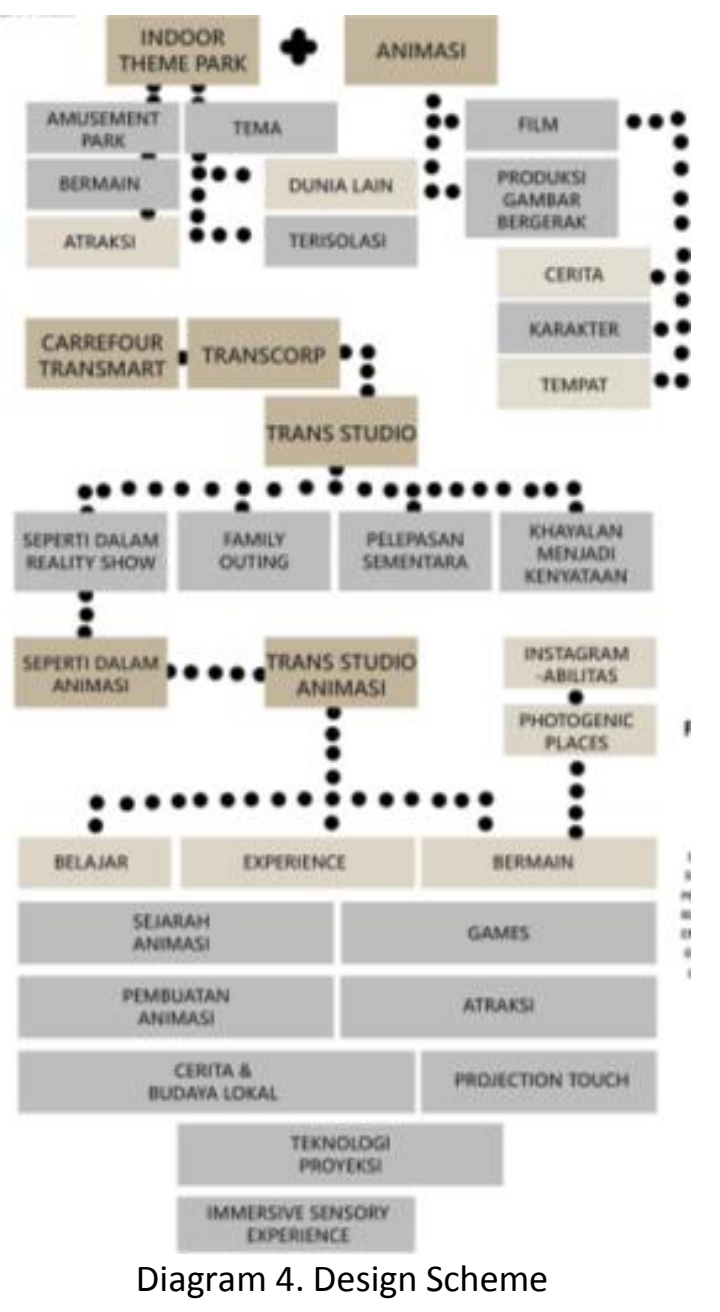

\section{Pembentukan Gubahan Massa}

Bentuk dasar gubahan massa dimulai dari Gambar 20. Hasil Akhir Bentuk Bangunan.

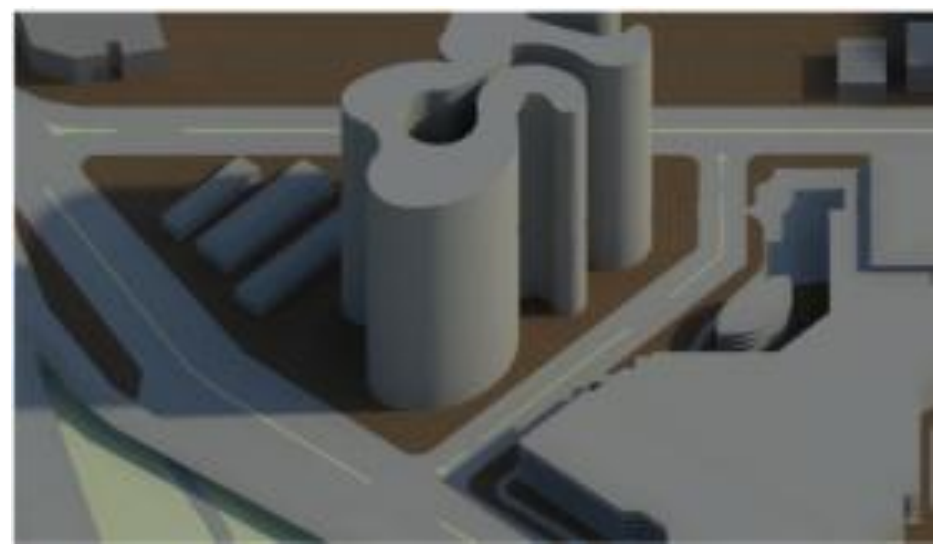

Gambar 21. Gubahan Massa 1

Karena peruntukan tapak yang menandakan sebagai sebuah tower, bentuk ditarik untuk membentuk sebuah tower. Bentuk terlihat massif dan polos. 


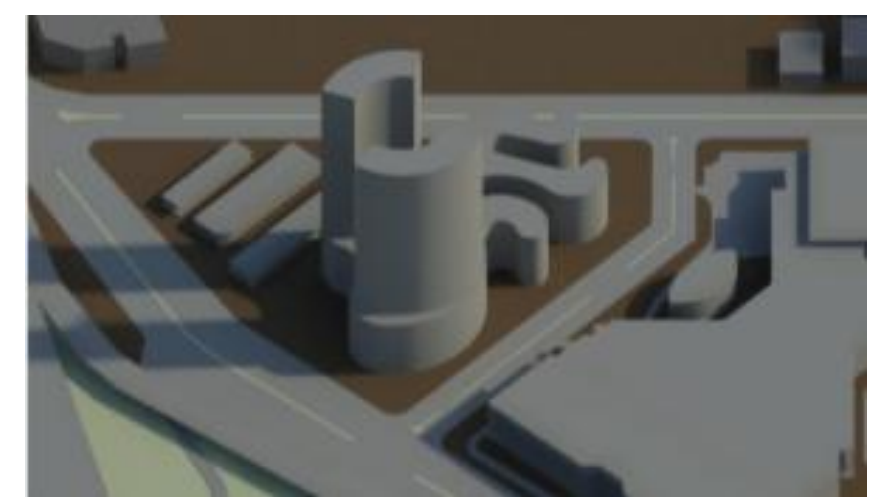

Gambar 22. Gubahan Massa 2

Bagian tower dipilih, tower terbuka ke arah simpang tol. Bagian tower inilah yang akan dijadikan bagian hotel, dan merupakan diluar rancangan desain proyek. Bagian bangunan yang direndahkan akan berfungsi sebagai Trans Studio Animasi.

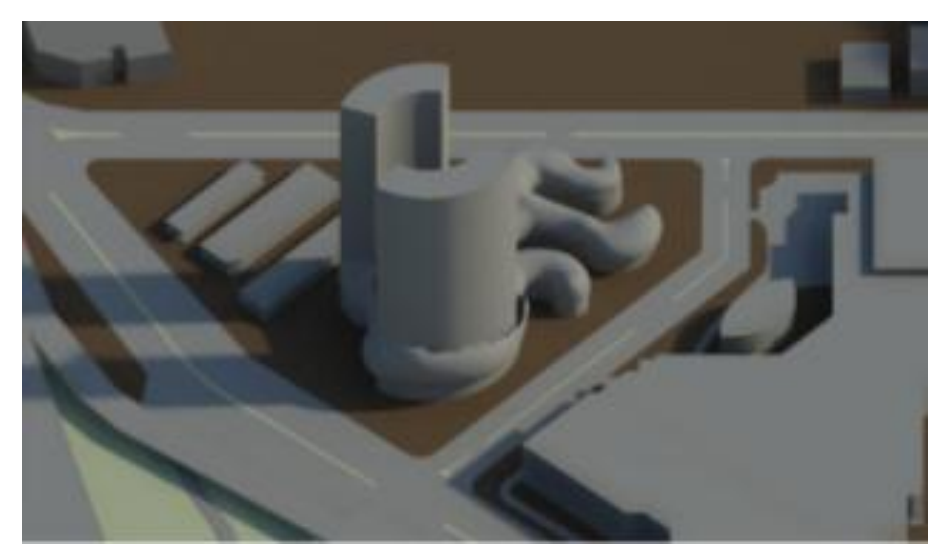

Gambar 23. Gubahan Massa 3

Menggunakan konsep "Negeri Diatas Awan", bagian podium Trans Studio Animasi dibentuk dan dilekukan untuk meneyrupai "awan". Pengunjung Trans Studio Animasi bermain di "awan".

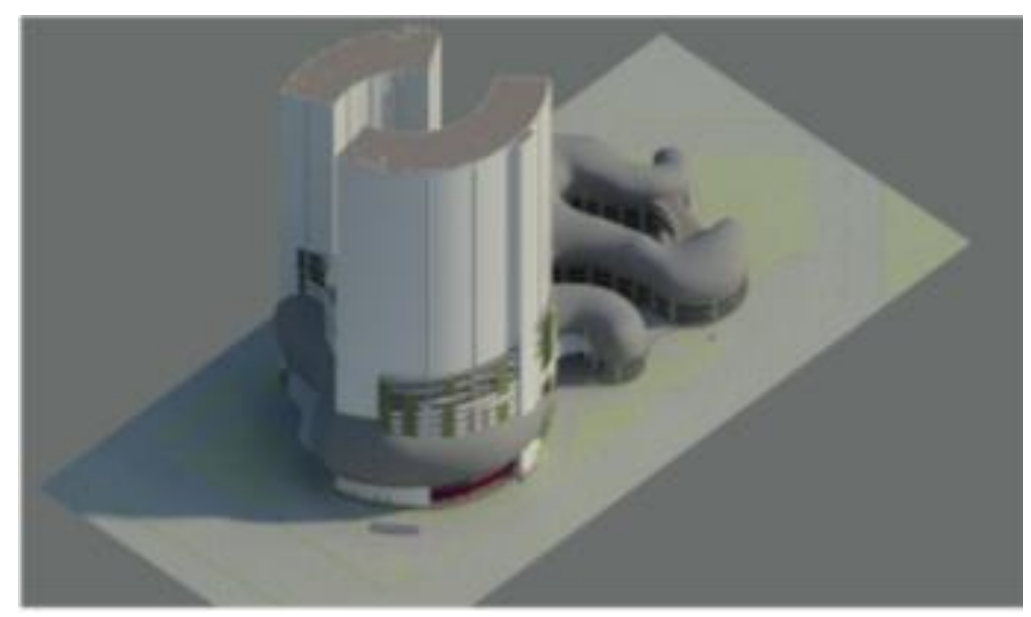

Gambar 24. Gubahan Massa 4

Ini adalah bentuk akhir setelah proses perancangan. Diantara podium dan hotel ditambahkan beberapa lantai untuk parkir. Bagian core bangunan dipilih dan ditonjolkan, dan terdapapt tambahan jembatan untuk memperlancar sirkulasi bangunan. 


\section{KESIMPULAN}

Program yang diusulkan adalah Trans Studio Animasi yang bertujuan untuk menyajikan hiburan berbentuk animasi, dan menyediakan tempat untuk para seniman lokal untuk berkreasi. Lokasinya pada CBD Puri Kembangan, sebagai kawasan yang sudah memiliki banyak fasilitas, dapat diterapkan sebuah sistim pembentukan kawasan wisata hiburan. Dengan ini, daerah sekitar Puri Indah Mall bisa dimanfaatkan secara lebih efektif dapat digunakan untuk meningkatkan pendapatan daerah DKI Jakarta. Fungsinya sebagai tempat wisata hiburan untuk wisatawan zaman milenial menekankan kebutuhannya bangunan unik. Bentuk bangunan yang dihasilkan adalah hasil dari studi tapak, dengan konsep "negri diatas awan".

\section{REFERENSI}

Bruce Hayllar, Tony Griffin, Deborah Edwards. (2008). City Places Tourist Spaces, ButterworthHeinemann, United Kingdom

Dridea Catrinel, Strutzen Gina, (2008) Theme Park - The Main Concept of Industry Developement, Romanian American Univerity, Bucharest

Jan Specht. (2014). Architectural Tourism : Building for Urban Travel Destinations, Gabler Verlag, Germany

The Urban Land Institute. (1999). Recreational Development Handbook, ULI-the Urban Land Institute, Washington, D.C

Rowan Moore. (2017). The Bilbao effect: how Frank Gehry's Guggenheim started a global craze, (didatangi 03/07/2018) https://www.theguardian.com/artanddesign/2017/oct/01/bilbao-effect-frank-gehryguggenheim-global-craze

Jakarta Dalam Angka https://jakarta.bps.go.id/ (didatangi 16/07/2018)

Creativiva, Cutting edge high tech entertainment productions, https://www.creativiva.com/high-tech-entertainment (didatangi 12/08/2018)

The Center of Genrational Kinetics. 2016. Gen Z Research and Findings, http://genhq.com/igen/ (didatangi pada 16/07/2018)

Emily Matchar, Smithsonian Mags. 2017. How Instagram is Changing the Way We Design Our Cultural Space,

https://www.smithsonianmag.com/innovation/how-instagram-changing-way-we-designcultural-spaces-180967071/ (Didatangi 16/07/2018) 